\title{
Pyrrolidin-2-one Structure Derivatives as Novel Ligands for Copper-based Atom Transfer Radical Polymerization (ATRP)
}

\author{
By Zhibiao HU, ${ }^{1}$ Wenting LIU, ${ }^{1}$ Haibo ZHANG,${ }^{1}$ Guilin XIAO, ${ }^{1}$ Xiaohai ZHOU, ${ }^{1}$
} Bilai XIA, ${ }^{2}$ Xinlin HONG ${ }^{1,2, *}$ and Gaoyong ZHANG ${ }^{1}$

(N-R) $)_{3}$ TEDP, 1,1'-(2,2'-(2,2'-(alkylazanediyl)bis(ethane-2,1-diyl)bis(alkylazanediyl))bis(ethane-2,1-diyl))dipyrrolidin-2-one, with central alkyl amine and peripheral pyrrolidin-2-one structure was successfully employed as ligand in copper-based ATRP. The polymerization followed the first order kinetic and the molecular weights of PMMA increased linearly with monomer conversion. Although the $M_{\mathrm{n}}$ of products obtained by SEC was higher than the theoretic ones, the distribution of molecular weight was narrow (<1.4). By introducing deactivator $\mathrm{CuBr}_{2}$, the polymerization rate of the ATRP catalyzed by $\mathrm{CuBr} /(N \text {-butyl })_{3}$ TEDP decreased dramatically, but the control was improved $\left(M_{\mathrm{w}} / M_{\mathrm{n}}=1.22\right)$. Using mixed halide initiation system $(\mathrm{CuCl} / \mathrm{EB} i \mathrm{~B})$, the $M_{\mathrm{n}}$ of synthesized PMMA was more close to the calculated value with much lower molecular weight distribution $\left(M_{\mathrm{w}} / M_{\mathrm{n}}=1.15\right)$. The effect of temperature was investigated and the low $\Delta H^{\theta}$ eq value $\left(21.38 \mathrm{~kJ} \cdot \mathrm{mol}^{-1}\right)$ was derived from the Arrhenius plot. The alkyl substitute of $(\mathrm{N}-\mathrm{R})_{3}$ TEDP had profound effect on the CuBr-catalyzed ATRP of MMA, due to the steric effect introduced by their bulky size. The activity of these ligands in the ATRP showed the following order: $\mathrm{C} 12 \ll \mathrm{C} 4 \sim \mathrm{C} 6 \sim \mathrm{C} 8$, in the abbreviate form of $(\mathrm{N}-\mathrm{R})_{3}$ TEDP.

KEY WORDS: Copper-based ATRP / Novel Ligand / Pyrrolidin-2-one Structure / Alkyl Substitute / Polymerization Kinetics /

Reported first in the mid-1990s, ${ }^{1-3}$ Atom transfer radical polymerization (ATRP) is a catalytic process in which, a transition metal complex reversibly activates the dormant polymer chains via a halogen atom transfer reaction (Scheme 1). ${ }^{4,5}$ As one of the most versatile techniques to synthesize well-defined polymers with narrow molecular weight distributions, ${ }^{6}$ ATRP has been utilized successfully to prepare block, ${ }^{7-9}$ graft, ${ }^{10-12}$ comb, ${ }^{13}$ star, ${ }^{14}$ hyperbranched copolymers, ${ }^{15}$ inorganic/organic hybrids (co)polymers ${ }^{16}$ and liquid-crystalline polymers ${ }^{17}$ in the past decades. Considerable research has been conducted in order to develop these welldefined polymers for wide applications from the coatings industry ${ }^{18}$ to the drug delivery ${ }^{19}$ and biotechnology. ${ }^{20}$

Nowadays, there are a variety of transition metal complexes, including the $\mathrm{Cu},{ }^{1} \mathrm{Ru},{ }^{2} \mathrm{Pd},{ }^{21} \mathrm{Rh},{ }^{22} \mathrm{Re},{ }^{23} \mathrm{Fe},{ }^{24} \mathrm{Ni},{ }^{25}$ have been found to be the effective catalysts in ATRP. Among these, $\mathrm{Cu}$ complex catalysts have attracted much attention because of their versatility and low cost. $^{26}$ Nitrogen-containing compounds, such as $2,2^{\prime}$-bispyridine ${ }^{1}$ and its derivatives, ${ }^{27}$ linear and branched aliphatic amine, ${ }^{28,29}$ terpyridy $^{30}$ and picolyl ${ }^{31}$ et al., have been used as ligands for copper-based ATRP. And the results have shown that the structural, and electronic properties of a ligand have a significant influence on the catalytic activity and the control of the polymerization. ${ }^{32,33}$

Matyjaszewski et al. demonstrated that the lower the redox potential is, the higher the activity of copper complex in ATRP is. ${ }^{34}$ And the activation rate depends on the nature of the nitrogen-binding site of the ligands. ${ }^{33,35}$ They also found that the activities of complexes with tridentate ligands decrease in the following order: alkylamine $\approx$ pyridine $>$ alkylimine $\gg$ arylimine $>$ arylamine. ${ }^{33}$ Subsequently, Tang et al. reported that the activities of $\mathrm{Cu}$ complexes demonstrate the following order: tetradentate (cyclic-bridged) $>$ tetradentate (branched) $>$ tetradentate $($ cyclic $)>$ tridentate $>$ tetradentate (linear) $>$ bidentate ligands. ${ }^{35}$ Some research revealed that ethylene is a better linkage for $\mathrm{N}$ atoms in the ligand than propylene. ${ }^{4}$ However, to our knowledge, there has been no report of copperbase ATRP using pyrrolidin-2-one derivatives as ligands.

Recently, we have developed a series of easily synthesized $N$-containing compounds (N-R) $)_{3}$ TEDP, ${ }^{36} 1,1^{\prime}$ - $\left(2,2^{\prime}-\left(2,2^{\prime}\right.\right.$-(alkylazanediyl)bis(ethane-2,1-diyl)bis(alkylazanediy))bis(ethane2,1-diyl))dipyrrolidin-2-one (see Scheme 2), used as ligand for copper-mediated ATRP. Compared with $N, N, N^{\prime}, N^{\prime \prime}, N^{\prime \prime}$-pentamethyldiethylenetriamine (PMDETA), a widely used ligand, these compounds have peripheral pyrrolidin-2-one structure, in which the carbonyl group could coordinate with the copper atom too. ${ }^{37}$ However, the acylamino group of the ligands might be inactive for $\mathrm{Cu}$-based ATRP. ${ }^{34}$ To better understand the structure-property relationship of these new compounds, we conducted copper mediated ATRP by using these dipyrrolidin2-one derivatives as new ligands. The influence of several factors, such as halide exchanges, the dosage of deactivator $\mathrm{CuBr}_{2}$ and the alkyl substitute of the ligands, on the control of the polymerization was reported herein in this paper.

\section{EXPERIMENTAL}

\section{Materials}

All chemicals were purchased from commercial sources. Methyl methacrylate was washed with $5 \%$ solution of sodium

\footnotetext{
${ }^{1}$ College of Chemistry and Molecular Science, Wuhan University, Wuhan 430072, China

${ }^{2}$ Daoqum (Zhongshan) Chemical Enterprise Ltd., Zhongshan 528403, China

*To whom correspondence should be addressed (Tel: +86-27-87218554, Fax: +86-27-87218534, E-mail: hongxl@whu.edu.cn).
} 

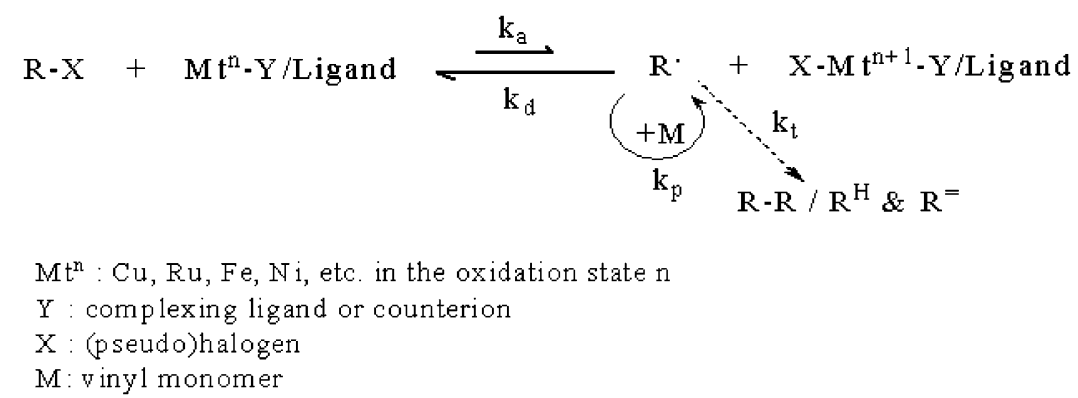

Scheme 1. Transition metal catalyzed ATRP.

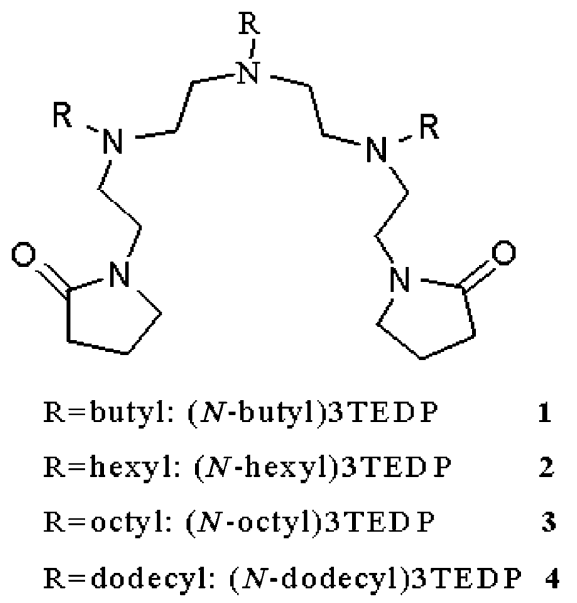

Scheme 2. The structure of ligands $(N-R)_{3}$ TEDP.

hydroxide, stirred over calcium hydroxide for $24 \mathrm{~h}$, then distilled under vacuum and stored at $-5{ }^{\circ} \mathrm{C}$ prior to use. Ethyl 2-bromoisobutyrate was used directly as received. $\mathrm{CuBr}$, $\mathrm{CuBr}_{2}, \mathrm{CuCl}$ (A.R.) were purified according to the literature. ${ }^{38}$ The ligands $1,1^{\prime}$-(2,2' -(2,2' -(alkylazanediyl)bis(ethane-2,1-diyl)bis(alkylazanediyl))bis(ethane-2,1-diyl))dipyrrolidin-2-one((N$\mathrm{R})_{3}$ TEDP) were prepared according to a literature procedure. ${ }^{36}$ $\mathrm{N}, \mathrm{N}$-dimethylformamide, tetrahydrofuran, anisole were used without further purification.

\section{Characterization}

Monomer conversion was determined by GC-MS (Thermo Finnigan DSQ) equipped with a fused silica capillary column (DB-5, $30 \mathrm{~m} \times 0.25 \mathrm{~mm} \times 0.25 \mu \mathrm{m}$ ) threaded into the ion source region of mass spectrometer (Thermo Finnigan Trace DSQ). Molecular weights and molecular weight distributions were measured using size exclusion chromatography (SEC) on a system equipped with a Waters 515 pump, a guard column (Mz gel SDplus Guard, $50 \times 7.5 \mathrm{~mm}$ ) followed by two columns (Mz gel SDplus linear column and $1 \mathrm{E}+03 \AA$ column, $2 \times$ $300 \times 7.5 \mathrm{~mm}$ ), with a Wyatt Optilab rEx RI detector and a Wyatt DAWN EOS multi-angle laser light scattering detector. Tetrahydrofuran (THF) was used as eluent at a flow rate of $1 \mathrm{~mL} \cdot \mathrm{min}^{-1}$ under $35^{\circ} \mathrm{C}$. ${ }^{1} \mathrm{H}$ NMR spectra were recorded with a Varian Mercury VX-300 MHz spectrometer at room temperature in $\mathrm{CDCl}_{3}$.

\section{Typical Polymerization Process}

A Schlenk tube was loaded with $\mathrm{CuBr}$ (1 equiv.), capped with a rubber septum, and cycled three times between vacuum and Nitrogen (high purity, 99.999\%) to remove oxygen. In another Schlenk tube, DMF (50 wt.-\%), ( $N$-butyl) 3 TEDP (1 equiv.), anisole (5 wt.-\%) used as internal reference for GC-MS and MMA (100 equiv.) were introduced. The resulting solution was degassed by bubbling with Nitrogen at least $1.5 \mathrm{~h}$ and then added to the first Schlenk tube containing $\mathrm{CuBr}$ via syringe. The Schlenk tube was placed in an oil bath and heated at the polymerization temperature until the solution became homogeneous. Then, the initiator ( 1 equiv. based on $\mathrm{CuBr}$ ) was added. Aliquots were taken periodically via a degassed syringe to follow the kinetic of the polymerization process. The aliquots were diluted with THF, one portion of it was used for GC-MS measurement to determine the monomer conversions and the rest of the dilute was used for the analysis by SEC after filtration through a basic alumina column.

\section{RESULTS AND DISCUSSION}

\section{Polymerization Studies}

Ligand 1 (Scheme 2) was tested for the homogeneous polymerization of MMA in DMF, under typical $\mathrm{Cu}$-based ATRP conditions, employing EBiB as initiator. And the results were collected in Table I. All of the polymerizations in this work were conducted in DMF solution due to the poor solubility of novel ligands in monomer and other solvent. The data shows that polymerizations using ligand $\mathbf{1}$ all proceeded via an ATRP mechanism: semilogarthmic plots of $\ln \left([\mathrm{M}]_{0} /[\mathrm{M}]_{\mathrm{t}}\right)$ vs time (Figure 1a) were linear, indicating that the radical concentration is constant through the polymerization. ${ }^{4}$ Molecular weight increases linearly with increasing conversion, and polydispersities are ca. 1.4 and decrease with increasing monomer conversion (Figure 1b). The molecular weights are higher than predicted, but there is no accompanying loss in control $\left(M_{\mathrm{w}} / M_{\mathrm{n}}<1.40\right)$. This was possibly due to the slow and inefficient initiation process of $\mathrm{EBiB} / \mathrm{CuBr} /(N-$ butyl $)_{3}$ TEDP system with the effect of irreversible propagating radical trapping on initiator efficiencies. ${ }^{39}$ A successful ATRP initiating system requires that the apparent initiation rate constant $\left(k_{\mathrm{i}}{ }^{\text {app }}\right)$ should be larger than the apparent propagation rate constant $\left(k_{\mathrm{p}}{ }^{\text {app }}\right){ }^{40}$ It appears that for the $\mathrm{EB} i \mathrm{~B} / \mathrm{CuBr}$ 
Table I. Copper-based ATRP of MMA with $(N \text {-butyl) })_{3}$ TEDP as ligands

\begin{tabular}{|c|c|c|c|c|c|c|c|c|}
\hline Entry & {$[\mathrm{M}]_{0}:[\mathrm{l}]_{0}:[\mathrm{Cu}]_{0}:[\mathrm{L}]_{0}{ }^{a}$} & Catalyst & $T\left({ }^{\circ} \mathrm{C}\right)$ & $t(\mathrm{~h})$ & Conv. (\%) & $M_{\mathrm{n}, \mathrm{Th}^{b}}{ }^{b}$ & $M_{\mathrm{n}, \mathrm{SEC}}$ & PDI \\
\hline 1 & $100: 1: 1: 0.5$ & $\mathrm{CuBr}$ & 70 & 7.5 & 36.4 & 3830 & 9630 & 1.39 \\
\hline 2 & $100: 1: 1: 1$ & $\mathrm{CuBr}$ & 70 & 9.5 & 71.2 & 7315 & 14500 & 1.38 \\
\hline 3 & $100: 1: 1: 2$ & $\mathrm{CuBr}$ & 70 & 10 & 87.8 & 8970 & 16240 & 1.33 \\
\hline 4 & $100: 1: 2: 2$ & $\mathrm{CuBr}$ & 70 & 8 & 82.0 & 8395 & 12400 & 1.38 \\
\hline 5 & $100: 1: 0.5: 0.5$ & $\mathrm{CuBr}$ & 70 & 10 & 42.1 & 4405 & 13070 & 1.39 \\
\hline
\end{tabular}

${ }^{a}$ The polymerizations were perfomed in DMF (50 wt.-\%) with EB/B as initiator $(\mathrm{I}),(\mathrm{N} \text {-butyl })_{3}$ TEDP as ligand $(\mathrm{L}), \mathrm{MMA}$ as $\mathrm{monomer}(\mathrm{M}),[\mathrm{M}]_{0}=4.7 \mathrm{M} .[\mathrm{Cu}]_{0}$ were the initiation concentration of $\mathrm{CuBr} .{ }^{b} M_{\mathrm{n}, \mathrm{Th}}$ was calculated by $M_{\mathrm{n}, \mathrm{Th}}=M_{\mathrm{w}}$ (initiator) $+M_{\mathrm{w}}($ monomer $) \times[\mathrm{M}]_{0} /[\mathrm{I}]_{0} \times$ conv .
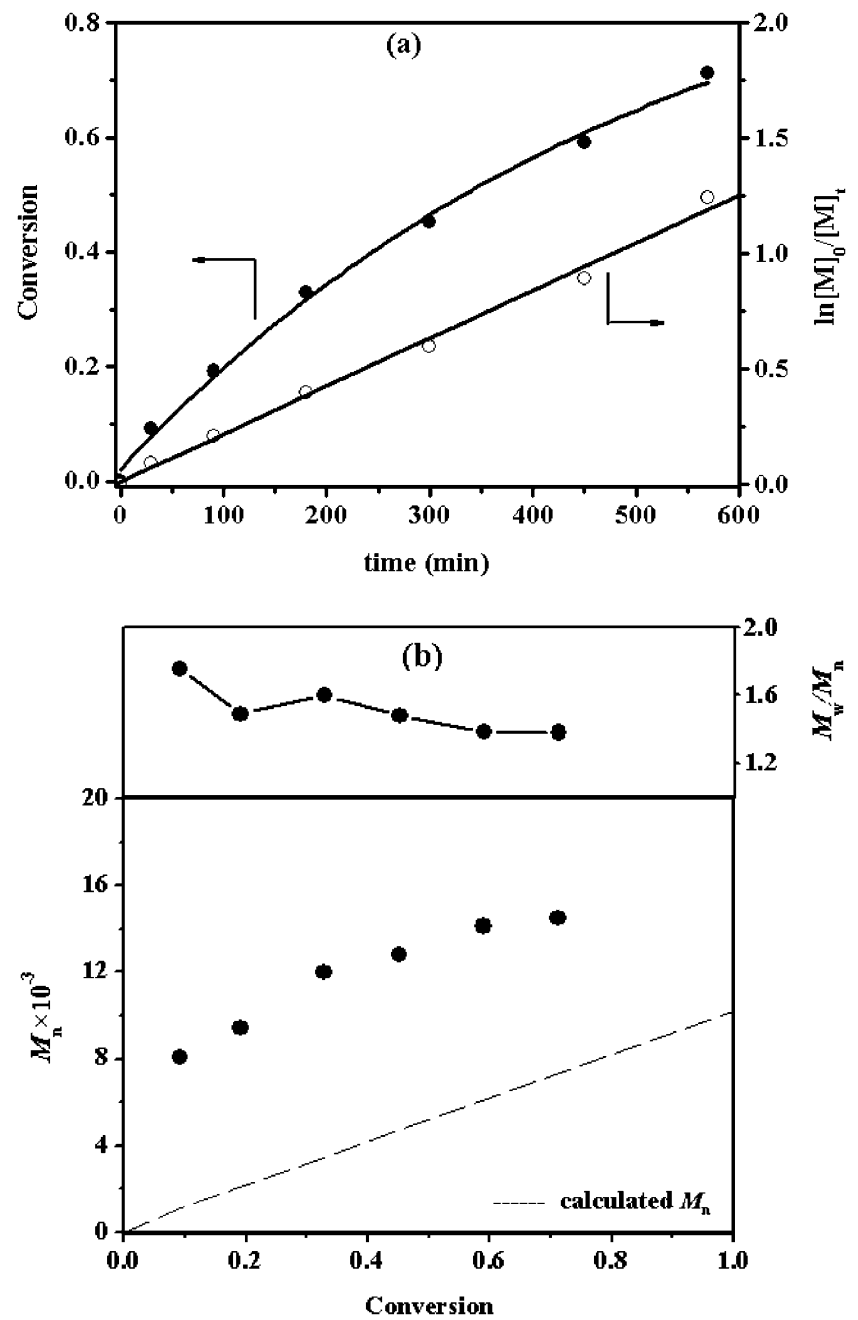

Figure 1. (a) Dependence of conversion and $\ln [\mathrm{M}]_{0} /[\mathrm{M}]_{t}$ on time, (b) Evolution of the molecular weights and polydispersity for the ATRP of MMA using ( $N$-butyl) $)_{3}$ TEDP as ligand in the DMF at $70^{\circ} \mathrm{C},[\mathrm{MMA}]_{0}=4.7 \mathrm{M},[\mathrm{MMA}]_{0}:[\mathrm{EB} / \mathrm{B}]_{0}:[\mathrm{CuBr}]_{0}:[\mathrm{L}]_{0}=100: 1: 1: 1$.

system in this study $k_{i}^{\text {app }}$ may be smaller than the observed propagation rate constant $k_{p}{ }^{\text {app }}$. $\mathrm{EB} i \mathrm{~B}$, though structurally similar to propagating species of methacrylates, is some less active in our polymerization system. The reason of the slow initiation may be ascribed to the steric bulky ligand used in polymerization system.

To get better understanding on the ATRP of MMA catalyzed by $\mathrm{CuX} /(\mathrm{N}-\mathrm{R})_{3}$ TEDP, which may lead to get wellcontrolled polymerization, the influence of deactivator $\mathrm{CuBr}_{2}$, halide exchange, temperature and alkyl substitute of ligands were studied. The polymerizations were performed with a $100: 1: 1: 1$ stoichiometry of $[\mathrm{M}]_{0}:[\mathrm{I}]_{0}:[\mathrm{Cu}]_{0}:[\mathrm{L}]_{0}$ as the most ATRP processes.

\section{Influence of Deactivator $\mathrm{CuBr}_{2}$}

To investigate the effect of the deactivator $\mathrm{CuBr}_{2}$ on the control of polymerization, a series of polymerizations were carried out by changing the amount of $\mathrm{CuBr}_{2}$. The results were collected in Table II. The polymerization behavior (Figure 2) were found to proceed the similar ATRP manner, affording first-order kinetics with respect to monomer concentration and a linear increase in molecular weight with conversion. But, as the concentration of $\mathrm{CuBr}_{2}$ increased, the polymerization became well-controlled $\left(M_{\mathrm{w}} / M_{\mathrm{n}}=1.38\right.$ decease to 1.22$)$.

The results revealed that initial addition of $\mathrm{Cu}(\mathrm{II})$ affected the kinetics of the ATRP. The apparent rate constant of polymerization $\left(k_{\mathrm{p}}{ }^{\text {app }}\right.$, Table II) is in the same magnitude as the most ATRP processes, and decreases with the dosage of $\mathrm{CuBr}_{2}$ in the system. This result is slightly different from the literature, ${ }^{41}$ which concluded that there is an inverse first-order relationship between the polymerization rate and $[\mathrm{Cu}(\mathrm{II})]_{0}$. The relationship between $k_{\mathrm{p}}$ app and $\mathrm{Cu}$ (II) concentration in this work was not inverse first-order but showed a decay behavior, and the decreasing rate of $k_{\mathrm{p}}{ }^{\text {app }}$ became slow when the molar ratio of $\mathrm{Cu}$ (II) to the total copper concentration increased from 0.1 to 0.2 . This might be attributed to spontaneous formation of $\mathrm{Cu}$ (II), due to low levels of termination at the early stage of the polymerization, resulting in a higher concentration of $\mathrm{Cu}$ (II) in the system than predicted by the amount of added $\mathrm{Cu}$ (II).

\section{Effect of Halide Exchange}

The polymerization of MMA using mixed halide initiation system $(\mathrm{CuCl} / \mathrm{EB} i \mathrm{~B})$ was also investigated, and the results are summarized in Table II. The similar ATRP behavior was observed as above, affording first-order kinetics with respect to monomer concentration and a linear increase in molecular weight with conversion (Figure $3 \mathrm{a}$ and $3 \mathrm{~b}$ ). Meanwhile, the use of the mixed halide initiating system gave a better control of the molecular weight, the experimental values $\left(M_{\mathrm{n}, \mathrm{SEC}}\right)$ were more close to theoretical values $\left(M_{\mathrm{n}, \mathrm{Th}}\right)$, and the distribution of molecular weight was narrow $\left(M_{\mathrm{w}} / M_{\mathrm{n}}=1.15\right)$. This is attributed to the preferential end-capping of the activated polymer chains by chloride over bromide which increases the relative rate of initiation to that of propagation, because the $\mathrm{C}-\mathrm{Cl}$ bond is stronger than $\mathrm{C}-\mathrm{Br}^{42}$ As described before, a 
Table II. The effect of deactivator $\mathrm{CuBr}_{2}$ and halide exchange on the ATRP of MMA with $(N \text {-butyl })_{3}$ TEDP as ligand

\begin{tabular}{|c|c|c|c|c|c|c|c|c|}
\hline Entry $^{a}$ & $\begin{array}{l}\text { Catalyst } \\
{[\mathrm{Cu}]}\end{array}$ & $T\left({ }^{\circ} \mathrm{C}\right)$ & $t(\mathrm{~h})$ & Conv. (\%) & $\begin{array}{c}K_{\mathrm{p}}^{\mathrm{app}} \\
\left(\times 10^{-5} \mathrm{~S}^{-1}\right)^{c}\end{array}$ & $M_{\mathrm{n}, \mathrm{Th}}$ & $M_{\mathrm{n}, \mathrm{SEC}}$ & PDI \\
\hline 1 & $\mathrm{CuBr}$ & 70 & 9.5 & 71.2 & 3.45 & 7315 & 14500 & 1.38 \\
\hline 2 & $\begin{array}{l}90 \% \mathrm{CuBr}+ \\
10 \% \mathrm{CuBr}_{2}{ }^{b}\end{array}$ & 70 & 10 & 50.1 & 1.83 & 5205 & 10540 & 1.25 \\
\hline 3 & $\begin{array}{l}80 \% \mathrm{CuBr}+ \\
20 \% \mathrm{CuBr}_{2}{ }^{b}\end{array}$ & 70 & 10 & 41.7 & 1.44 & 4365 & 9700 & 1.22 \\
\hline 4 & $\mathrm{CuCl}$ & 70 & 10 & 60.2 & 2.45 & 6215 & 8290 & 1.15 \\
\hline
\end{tabular}

a The polymerizations were performed in DMF $(50 w t .-\% w / w)$ with EB/B as initiator (I), (N-butyl) 3 TEDP as ligand (L) and MMA as monomer (M), $[\mathrm{M}]_{0}=4.7 \mathrm{M},[\mathrm{M}]_{0}:[\mathrm{l}]_{0}:[\mathrm{Cu}]_{0}:[\mathrm{L}]_{0}=100: 1: 1: 1,[\mathrm{Cu}]_{0}$ were the initiation total concentration of copper salts including cuprous and cupric salt. ${ }^{b}$ The total concentration of copper salts $\left([\mathrm{Cu}]_{0}=[\mathrm{CuBr}]_{0}+[\mathrm{CuBr} 2]_{0}\right)$ kept constant, just changed the relative concentration $[\mathrm{CuBr}]_{0} /[\mathrm{Cu}]_{0}\left(\mathrm{molar}\right.$ percentage). ${ }^{c} \mathrm{The}$ apparent rate constant of polymerization $\left(k_{\mathrm{p}}^{\text {app }}\right)$, calculated by the slopes of kinetic plots of $\ln \left([\mathrm{M}]_{0} /[\mathrm{M}]_{\mathrm{t}}\right) v s$ reaction time.
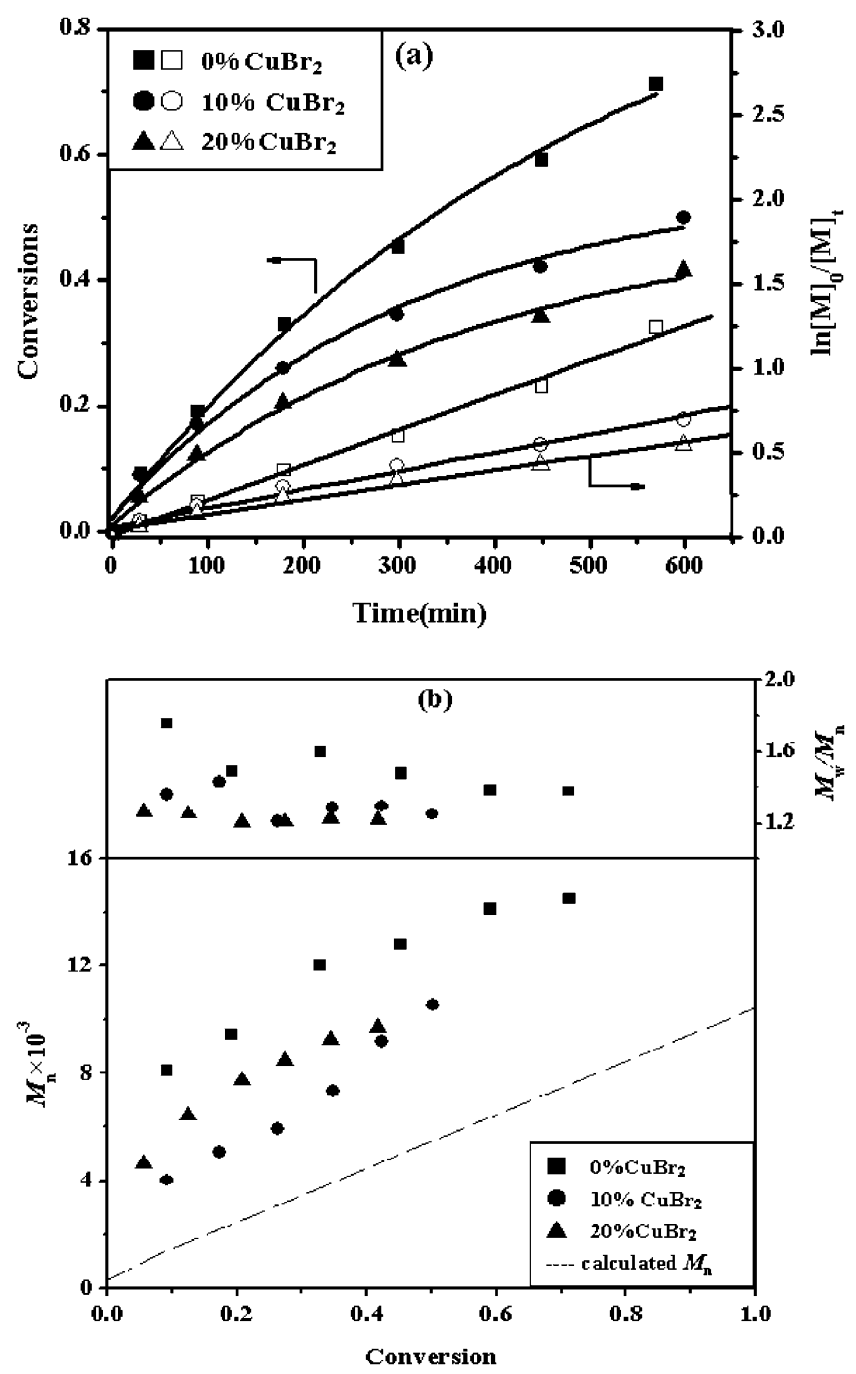

Figure 2. (a) Dependence of conversion and $\ln [\mathrm{M}]_{0} /[\mathrm{M}]_{t}$ on time, (b) Evolution of the molecular weights and polydispersity for the ATRP of MMA using ( $N$-butyl $)_{3}$ TEDP as ligand with different concentration of $\mathrm{CuBr}_{2}$ in the $\mathrm{DMF}$ at $70^{\circ} \mathrm{C}, \quad[\mathrm{MMA}]_{0}=$ $4.7 \mathrm{M},[\mathrm{MMA}]_{0}:[\mathrm{EBIB}]_{0}:[\mathrm{Cu}]_{0}:[\mathrm{L}]_{0}=100: 1: 1: 1 ;[\mathrm{Cu}]_{0}=[\mathrm{CuBr}]_{0}+$ $\left[\mathrm{CuBr}_{2}\right]_{0},\left[\mathrm{CuBr}_{2}\right]_{0} /[\mathrm{Cu}]_{0}=0(\square), 10 \%(\bigcirc), 20 \%(\triangle \boldsymbol{\Delta})$.

successful ATRP system requires $k_{\mathrm{i}}{ }^{\text {app }}>k_{\mathrm{p}}{ }^{\text {app }}$. Thus, the lower apparent rate constants of polymerization $\left(k_{\mathrm{p}}{ }^{\text {app }}\right)$ of $\mathrm{CuCl}$ indicate that halide exchange should be well-suited to this
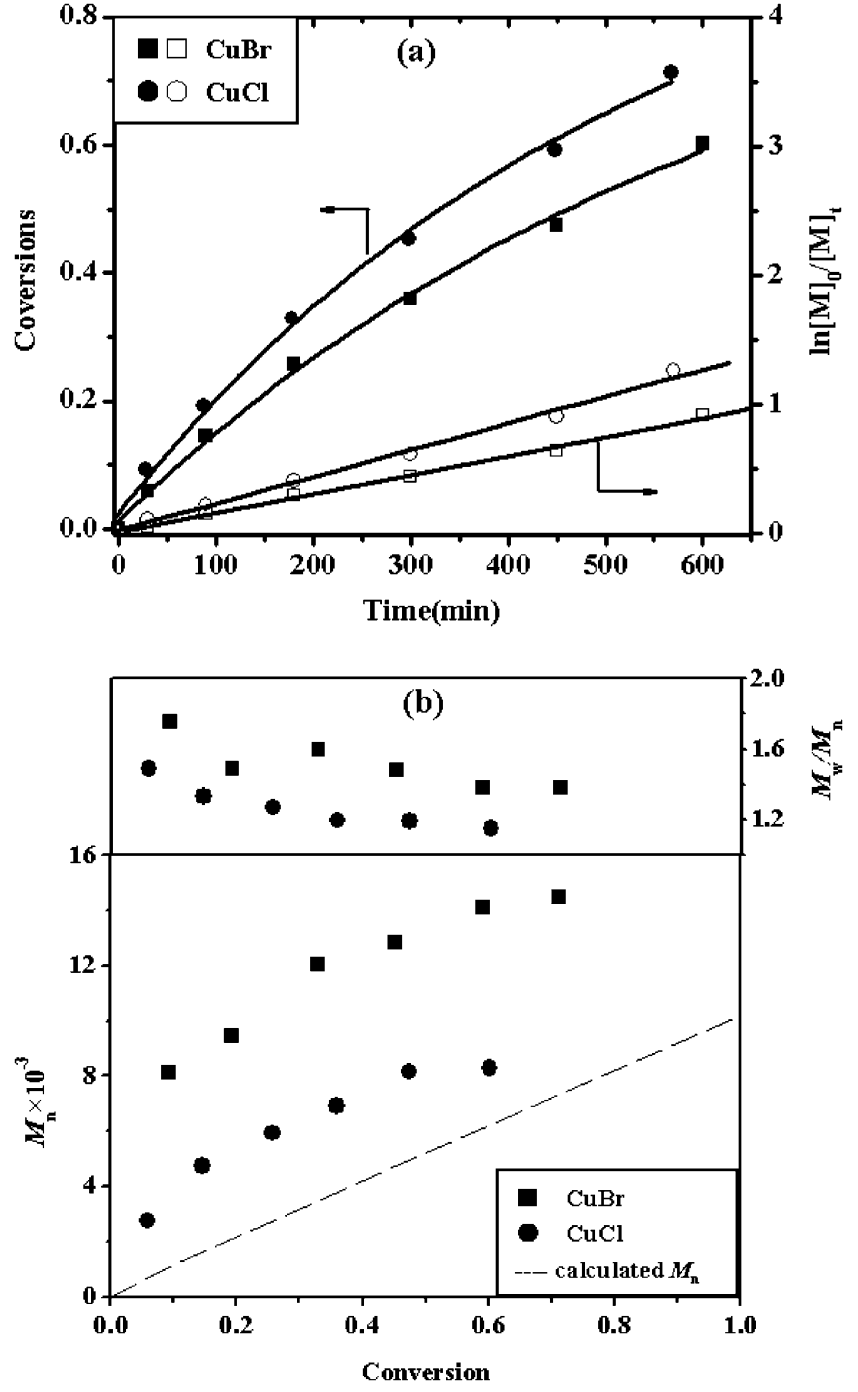

Figure 3. (a) Dependence of conversion and $\ln [\mathrm{M}]_{0} /[\mathrm{M}]_{\mathrm{t}}$ on time, (b) Evolution of the molecular weights and polydispersity for the ATRP of MMA using $(\mathrm{N} \text {-butyl })_{3}$ TEDP as ligand with different catalyst in the DMF at $70^{\circ} \mathrm{C},[\mathrm{MMA}]_{0}=4.7 \mathrm{M},[\mathrm{MMA}]_{0}:[\mathrm{EB} / \mathrm{B}]_{0}$ : $[\mathrm{CuX}]_{0}:[\mathrm{L}]_{0}=100: 1: 1: 1 ; \mathrm{CuBr}(\square \square), \mathrm{CuCl}(\bigcirc)$ as catalyst respectively.

ATRP catalysis. So halide exchange effectively improved the control of the ATRP of MMA with $\mathrm{CuCl} /(N \text {-butyl })_{3}$ TEDP as catalyst complex. 
Table III. The effect of temperature on the ATRP of MMA with ( $N$-butyl) $)_{3}$ TEDP as ligands

\begin{tabular}{|c|c|c|c|c|c|c|c|c|c|}
\hline Entry $^{a}$ & $T\left({ }^{\circ} \mathrm{C}\right)$ & $\begin{array}{c}t \\
\text { (h) }\end{array}$ & $\begin{array}{c}\text { Conv. } \\
(\%)\end{array}$ & $\begin{array}{c}k_{\mathrm{p}}^{\text {app }} \\
\left(\times 10^{-5} \mathrm{~S}^{-1}\right)^{b}\end{array}$ & $\begin{array}{c}k_{\mathrm{p}} \\
\left(\times 10^{3} \mathrm{~mol}^{-1} \cdot \mathrm{L} \cdot \mathrm{S}^{-1}\right)^{c}\end{array}$ & $\begin{array}{c}{\left[\mathrm{P}^{*}\right]^{d}} \\
\left(\times 10^{-8} \mathrm{~mol} \cdot \mathrm{L}^{-1}\right)\end{array}$ & $M_{\mathrm{n}, \mathrm{Th}}$ & $M_{\mathrm{n}, \mathrm{SEC}}$ & PDI \\
\hline 1 & 60 & 10 & 55.7 & 2.10 & 0.83 & 2.53 & 5765 & 10200 & 1.18 \\
\hline 2 & 70 & 9.5 & 71.2 & 3.45 & 1.05 & 3.29 & 7315 & 14500 & 1.38 \\
\hline 3 & 80 & 8 & 79.0 & 5.13 & 1.31 & 3.92 & 8090 & 13170 & 1.42 \\
\hline
\end{tabular}

${ }^{a}$ The polymerizations were performed in DMF $(50 \mathrm{wt} . \%)$ at different temperature with EBIB as initiator (I), (N-butyl) ${ }_{3}$ TEDP as ligand $(\mathrm{L})$ and MMA as

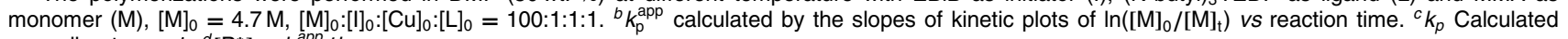
according to eq. $1 .{ }^{d}\left[\mathrm{P}^{*}\right]=k_{p}^{a p p} / k_{p}$.

\section{Effect of Temperature}

The effect of reaction temperature on the polymerization of MMA was studied in DMF (50wt.-\%) at $60^{\circ} \mathrm{C}, 70^{\circ} \mathrm{C}$ and $80^{\circ} \mathrm{C}$ (See Table III). All of the polymerizations at different temperature showed good linear relationship between $\ln \left([\mathrm{M}]_{0} /[\mathrm{M}]_{\mathrm{t}}\right)$ and polymerization time as shown in Figure $4 \mathrm{a}$. The polymerization rate increased with increasing temperature. According to the literature, ${ }^{43}$ eq 1 and eq 2 can be utilized to calculate the rate constant of radical propagation $k_{\mathrm{p}}$, and the stationary concentration of the propagating radicals $\left(\left[\mathrm{P}^{*}\right]\right)$ respectively. The data at different temperature were listed in Table III.

$$
\begin{aligned}
& k_{\mathrm{p}}=10^{6.423} \mathrm{dm}^{3} \mathrm{~mol}^{-1} \mathrm{~s}^{-1} \exp \left(\frac{-22.34 \mathrm{~kJ} \mathrm{~mol}^{-1}}{\mathrm{RT}}\right) \\
& R_{p}=-\mathrm{d}[\mathrm{M}] / \mathrm{dt}=k_{p}\left[\mathrm{P}^{*}\right][\mathrm{M}]=k_{p}^{\text {app }}[\mathrm{M}]
\end{aligned}
$$

The apparent activation energy $\left(\Delta E^{\neq}{ }_{a p p}=43.72 \mathrm{~kJ} \cdot \mathrm{mol}^{-1}\right)$ can be derived from the slope of Arrhenius plot of $\ln k_{\mathrm{p}}$ app versus $1 / T$ for the polymerizations (Figure 5). According to $\Delta H^{\theta}$ eq $=\Delta E^{f}$ app $-\Delta E^{\neq}$prop and $\Delta E^{\neq}$prop $=22.34 \mathrm{~kJ} \cdot \mathrm{mol}^{-1}$ for MMA ${ }^{43}$ an enthalpy change $\Delta H^{\theta}$ eq of $21.38 \mathrm{~kJ} \cdot \mathrm{mol}^{-1}$ was obtained for the ATRP of MMA catalyzed by $\mathrm{CuBr} /(N$ butyl $)_{3}$ TEDP. This $\Delta H^{\theta}$ eq value is smaller than $\Delta H^{\theta}$ eq $=$ $40.74 \mathrm{~kJ} \cdot \mathrm{mol}^{-1}$ for $p$-TsCl$/ \mathrm{CuCl}$-initiated ATRP of MMA with dNbpy as ligand in biphenyl ether, ${ }^{44}$ and $\Delta H^{\theta}$ eq $=28.8$ $\mathrm{kJ} \cdot \mathrm{mol}^{-1}$ for the $\mathrm{CuBr} / \mathrm{BPIEP}$ catalyzed ATRP of MMA initiated by $\mathrm{EB} i \mathrm{~B} .{ }^{45}$ This is because the $\mathrm{C}-\mathrm{Cl}$ bond was stronger than $\mathrm{C}-\mathrm{Br}$, and the lower activity of alkyl imine structure of BPIEP than the alkyl amine. ${ }^{33}$ The apparent polymerization rate constant, $k_{\mathrm{p}}{ }^{\text {app }}=7.83 \times 10^{-5} \mathrm{~S}^{-1}$, for ATRP of MMA catalyzed by $\mathrm{CuBr} /(N \text {-butyl })_{3} \mathrm{TEDP}$ at $90^{\circ} \mathrm{C}$ were calculated from the Arrhenius plot, which was some lower than the value $\left(k_{\mathrm{p}}{ }^{\text {app }}=1.13 \times 10^{-4} \mathrm{~S}^{-1}\right.$ at $\left.90^{\circ} \mathrm{C}\right)$ for ATRP of MMA catalyzed by $\mathrm{CuBr} / \mathrm{PMDETA}^{46}$

According to the above result, a conclusion could be deduced that the activity of ( $N$-butyl $)_{3}$ TEDP as ligand was more or less lower as the ones of PMDETA as ligand for Cu-based ATRP. This phenomenon can be possibly ascribed to the bulk alkyl substitute and pyrrolidinone structure of ( $N$-butyl $)_{3}$ TEDP. Ligands with phenyl-substituted imine and amine units formed inactive ATRP catalysts due to the strong electron-withdrawing effect of phenyl group. ${ }^{45}$ So the acylamino group in the pyrrolidinone unit of ( $N$-butyl $)_{3}$ TEDP might not be active for ligand of $\mathrm{Cu}$-based ATRP. The steric effect of bulk alkyl substitute led to the equilibrium between active and dormant species more slow to build and the catalyst more
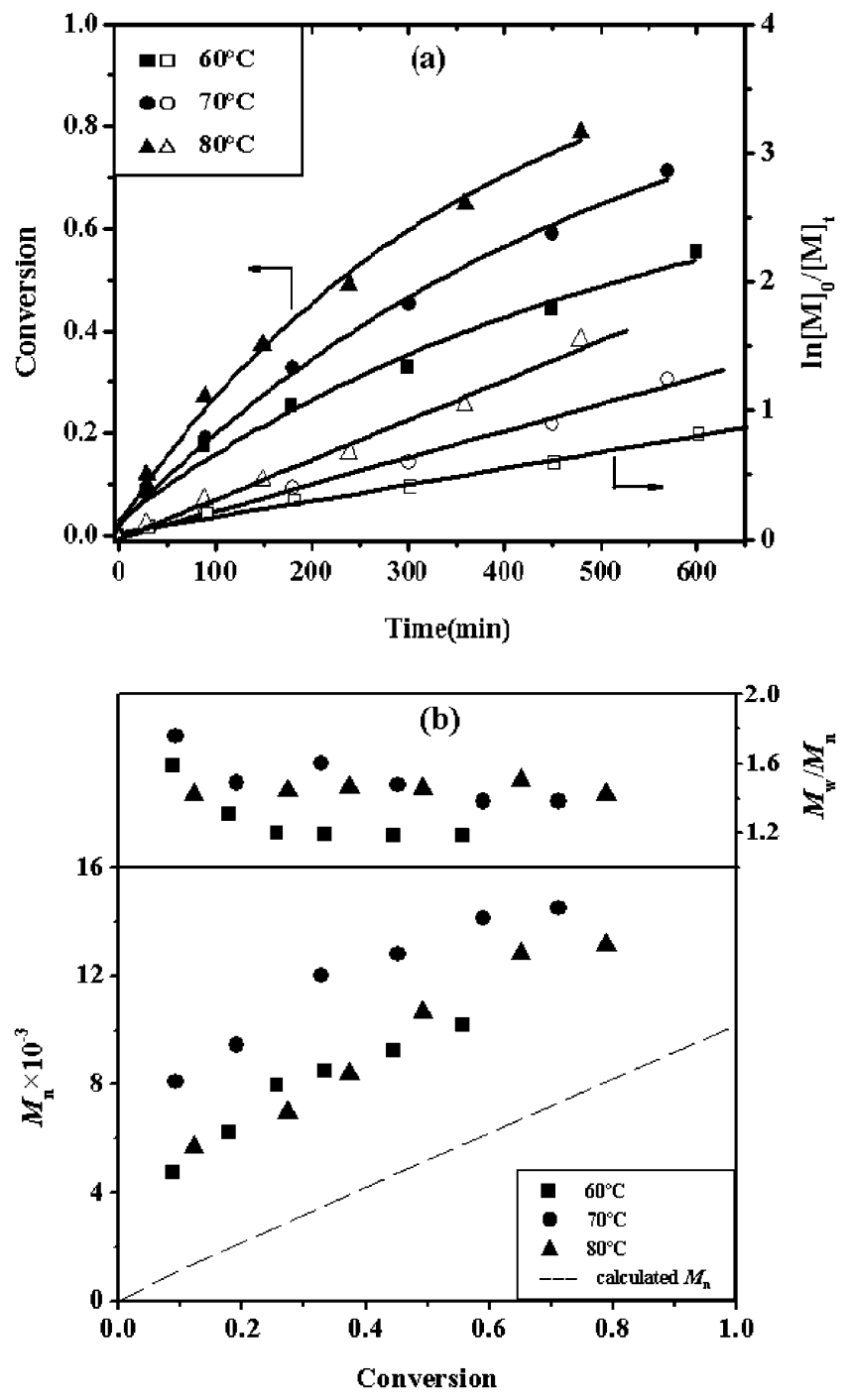

Figure 4. (a) Dependence of conversion and $\ln [\mathrm{M}]_{0} /[\mathrm{M}]_{\mathrm{t}}$ on time (b) Evolution of the molecular weights and polydispersity for the ATRP of MMA using ( $N$-butyl $)_{3}$ TEDP as ligand in the DMF at different temperature: $[\mathrm{MMA}]_{0}=4.7 \mathrm{M},[\mathrm{MMA}]_{0}:[\mathrm{EB} / \mathrm{B}]_{0}:[\mathrm{CuBr}]_{0}$ : $[\mathrm{L}]_{0}=100: 1: 1: 1 ; \mathrm{T}=60^{\circ} \mathrm{C}(\square \square), 70^{\circ} \mathrm{C}(\bigcirc \bigcirc), 80^{\circ} \mathrm{C}(\Delta \triangle)$.

difficult to contact with initiator and propagation radicals. The effect of alkyl substitute would be discussed below in detail.

Although higher temperature led to a faster rate of polymerization as expected (Figure 4b), the control of molecular weights distribution were sacrificed. On the other hand, the polydispersities of the PMMAs increased with the rising 


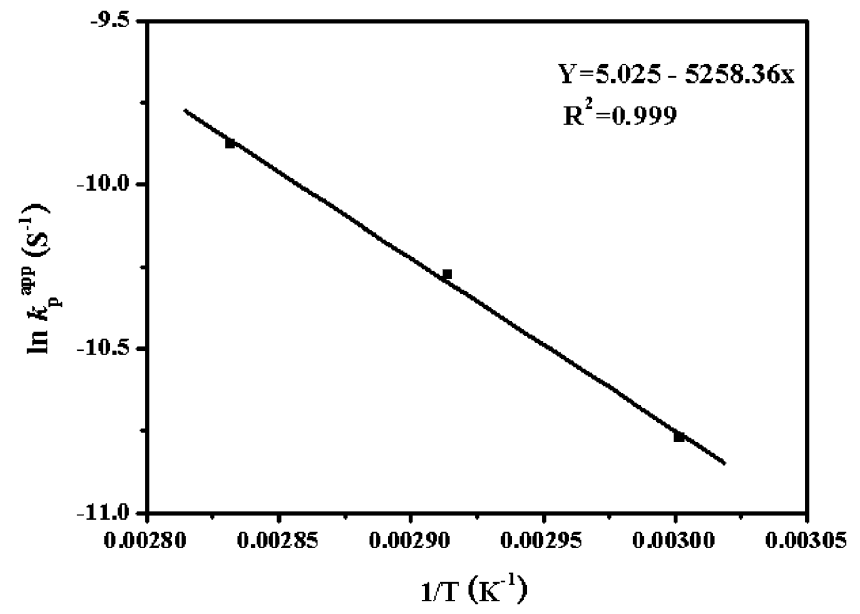

Figure 5. Plot of $\ln k_{\mathrm{p}}$ app versus $1 / T$ for ATRP of MMA initiated by EBiB with $\mathrm{CuBr} /(\mathrm{N} \text {-butyl })_{3}$ TEDP as catalyst in DMF: $[\mathrm{MMA}]_{0}=4.7 \mathrm{M}$, $[\mathrm{MMA}]_{0}:[\mathrm{EB} / \mathrm{B}]_{0}:[\mathrm{CuBr}]_{0}:\left[(N \text {-butyl })_{3} \text { TEDP }\right]_{0}=100: 1: 1: 1$.

temperature. This could be due to more pronounced termination and transfer reactions with higher concentration propagation radicals at higher temperature.

\section{Effect of Alkyl Substitute of Ligands}

Ligands 1, 2, 3 and 4 (Scheme 2) were used in the polymerizations of MMA, under the same conditions as described above. Because the monomer conversion just reached about $5 \%$ for $30 \mathrm{~h}$, the polymerization with $\mathbf{4}$ as ligand was considered nearly not occurred at $70^{\circ} \mathrm{C}$ and all data of $\mathbf{4}$ were collected at $90^{\circ} \mathrm{C}$. The results were presented in Table IV. The similar ATRP manners were observed for different ligands (Figure $6 \mathrm{a}$ and $6 \mathrm{~b}$ ). The polymerization rate $\left(k_{\mathrm{p}}{ }^{\text {app }}\right)$ seemed to be constant along with the increasing chain length of the alkyl substitute from $\mathrm{C} 4$ to $\mathrm{C} 8$ and then dramatically declined when $\mathrm{C} 12$ used. On the other hand, the polymerizations using ligands $\mathbf{2}$ and $\mathbf{3}$ are of a little but not obvious better-control of molecular weights compared with 1. However, the controllability of the polymerization was severely destroyed by using $\mathbf{4}$ as ligand, where the $M_{\mathrm{n}, \mathrm{SEC}}$ was greatly deviated the theoretic values and the distribution of molecular weight was broad.

The results showed that the bulk alkyl substitute of $(\mathrm{N}$ R) ${ }_{3}$ TEDP had profound effect on the CuBr-catalyzed ATRP of MMA, and the activity of these ligands in the ATRP showed the following order: $\mathrm{C} 12 \ll \mathrm{C} 4 \sim \mathrm{C} 6 \sim \mathrm{C} 8$, in the abbreviate form of $(\mathrm{N}-\mathrm{R})_{3}$ TEDP. The probable reason is the steric
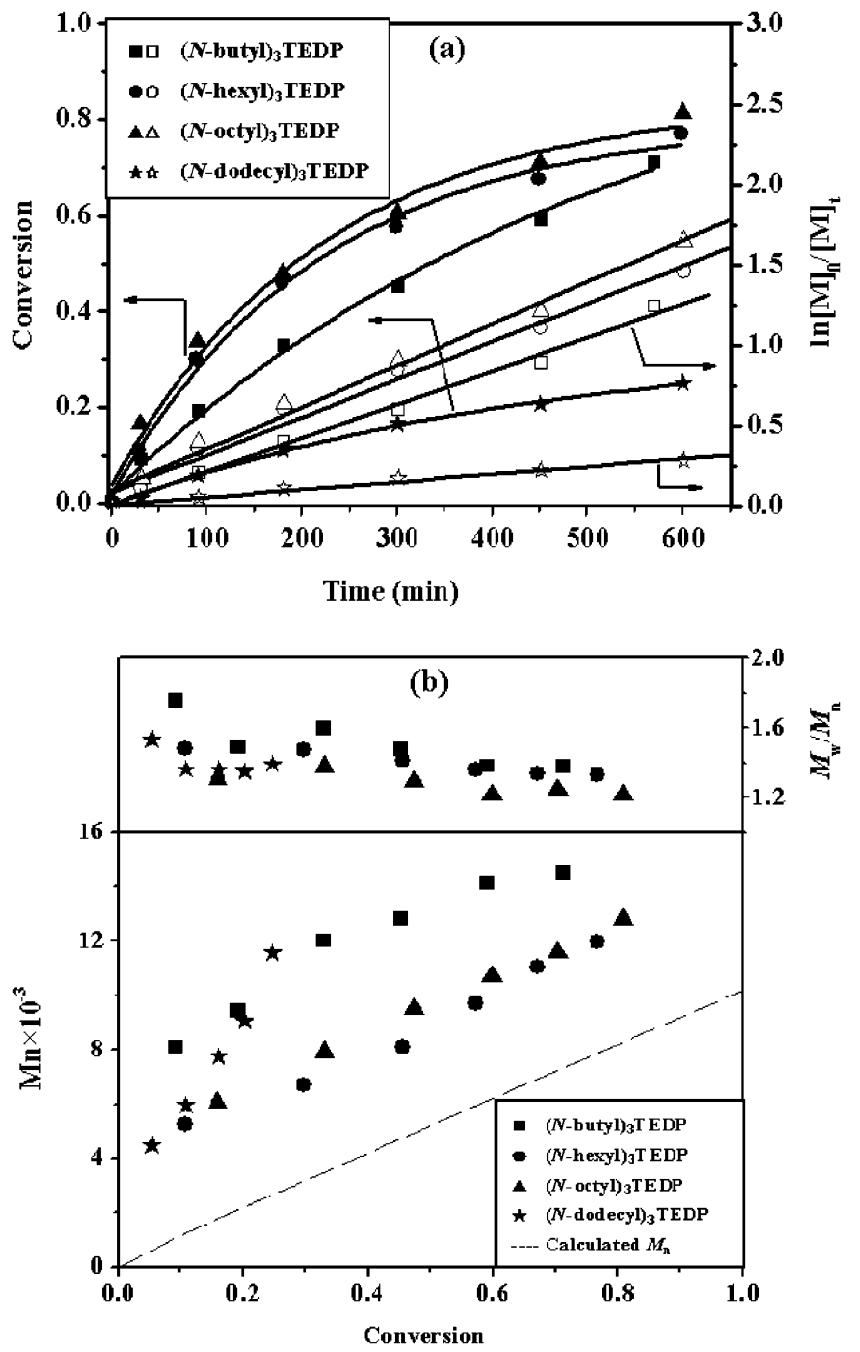

Figure 6. (a) Dependence of conversion and $\ln [\mathrm{M}]_{0} /[\mathrm{M}]_{t}$ on time, (b) Evolution of the molecular weights and polydispersity for the ATRP of MMA with different ligands. All polymerization were performed in DMF at $70^{\circ} \mathrm{C}$ except $(\mathrm{N} \text {-dodecyl })_{3}$ TEDP as ligand at $90^{\circ} \mathrm{C},[\mathrm{MMA}]_{0}=4.7 \mathrm{M},[\mathrm{MMA}]_{0}:[\mathrm{EBIB}]_{0}:[\mathrm{CuBr}]_{0}:[\mathrm{L}]_{0}=100: 1: 1: 1$; ( $N$-butyl $)_{3}$ TEDP $(\square \square),(N \text {-hexyl })_{3}$ TEDP $(\bigcirc)$ ), $(N \text {-octyl })_{3}$ TEDP $(\mathbf{\Delta} \triangle),(N \text {-dodecyl })_{3}$ TEDP $(\star \varkappa)$ as ligand respectively.

hindrance effect of the alkyl substitute as mentioned above. When the alkyl chain length of (N-R) $)_{3}$ TEDP was not great ( $\leq 8$ in this study), the steric effect was not distinct enough to impair the activity of catalyst complex. And there was a little improving the control of the polymerization by using ligand with long alkyl substitute as shown in Table IV, possibly due to the more bulky of ligand with longer alkyl substitute, the more

Table IV. The influence of alkyl substitute of $(\mathrm{N}-\mathrm{R})_{3}$ TEDP for Cu-based ATRP of MMA

\begin{tabular}{|c|c|c|c|c|c|c|c|c|}
\hline Entry ${ }^{a}$ & Ligands & $T\left({ }^{\circ} \mathrm{C}\right)$ & $t(\mathrm{~h})$ & $\begin{array}{c}\text { Conv. } \\
(\%)\end{array}$ & $\begin{array}{c}k_{\mathrm{p}}^{\mathrm{app}} \\
\left(\times 10^{-5} \mathrm{~S}^{-1}\right)^{b}\end{array}$ & $M_{\mathrm{n}, \mathrm{Th}}$ & $M_{\mathrm{n}, \mathrm{SEC}}$ & PDI \\
\hline 1 & $(N \text {-butyl })_{3}$ TEDP & 70 & 9.5 & 71.2 & 3.45 & 7315 & 14500 & 1.38 \\
\hline 2 & $(N \text {-hexyl })_{3}$ TEDP & 70 & 10 & 76.8 & 3.92 & 7870 & 11950 & 1.33 \\
\hline 3 & $(N \text {-octyl })_{3}$ TEDP & 70 & 10 & 80.8 & 4.32 & 8275 & 12810 & 1.21 \\
\hline 4 & $(N \text {-dodecyl })_{3}$ TEDP & $90^{c}$ & 10 & 24.7 & 0.8 & 2665 & 11560 & 1.39 \\
\hline
\end{tabular}

${ }^{a}$ The polymerizations were performed in DMF (50wt.-\%) with $\mathrm{EB} / \mathrm{B}$ as initiator (I), MMA as monomer (M) using different ligands, $[\mathrm{M}]_{0}=4.7 \mathrm{M}$, $[\mathrm{M}]_{0}:[\mathrm{I}]_{0}:[\mathrm{Cu}]_{0}:[\mathrm{L}]_{0}=100: 1: 1: 1 .{ }^{b} \mathrm{~K}_{\mathrm{p} p}^{\text {app }}$ calculated by the slopes of kinetic plots of $\ln \left([\mathrm{M}]_{0} /[\mathrm{M}]_{\mathrm{t}}\right)$ vs reaction time. ${ }^{c}$ Due to the monomer conversion just reached about $5 \%$ for $30 \mathrm{~h}$, so polymerization with $\mathbf{4}$ as ligand was considered nearly not occurred at $70^{\circ} \mathrm{C}$ and all data of ligand $\mathbf{4}$ were collected at $90^{\circ} \mathrm{C}$. 
feasible to trap the propagation radicals by the catalyst complex. The steric effect became pronounced to destroy the activity of catalyst when using ( $N$-dodecyl $)_{3}$ TEDP as ligand. There seem to be a threshold value of the length of alkyl substitute. The activity of ligand decreased dramatically just when the length of alkyl substitute was above the threshold value by our study.

\section{CONCLUSION}

The derivatives of pyrrolidin-2-one, $(\mathrm{N}-\mathrm{R})_{3}$ TEDP as ligands were successfully employed in copper-based ATRP of MMA. The polymerization followed the first order kinetic and the molecular weights of PMMAs increased linearly with monomer conversion. Although the obtained $M_{\mathrm{n}}$ by SEC of products was higher than the theoretical ones, the distribution of molecular weight was narrow $\left(M_{\mathrm{w}} / M_{\mathrm{n}}<1.4\right)$. The polymerization rate for the ATRP of MMA with (N-R) 3 TEDP as ligand at $[\mathrm{M}]_{0}:[\mathrm{I}]_{0}:[\mathrm{Cu}]_{0}:[\mathrm{L}]_{0}=100: 1: 1: 1$, decreased dramatically by introducing $\mathrm{CuBr}_{2}$, but the control of molecular weight was improved. Under halide exchange conditions with $\mathrm{CuCl}$ as catalyst for ATRP, the synthesized PMMA is more close to the calculated $M_{\mathrm{n}, \mathrm{Th}}$ with narrow molecular weight distribution of 1.15. The effect of temperature was investigated and the low $\Delta H^{\theta}$ eq value $\left(21.38 \mathrm{~kJ} \cdot \mathrm{mol}^{-1}\right)$ for ATRP of MMA catalyzed by $\mathrm{CuBr} /(N \text {-butyl })_{3}$ TEDP was calculated from the Arrhenius plot. The alkyl substitute structure of ligands (N-R) $)_{3}$ TEDP had strong influence on the control of ATRP, and the activity of these ligands in the ATRP demonstrated the following order: $\mathrm{C} 12 \ll \mathrm{C} 4 \sim \mathrm{C} 6 \sim \mathrm{C} 8$, in the abbreviate form of $(\mathrm{N}-$ R) ${ }_{3}$ TEDP. This result could be ascribed to the steric effect of ligands caused by the alkyl substitute with different length.

Acknowledgment. The authors gratefully acknowledge the financial support of the National Science Foundation of China (NSFC-20433060), Canxueyan Cooperative Projects of Guangdong Province and Ministry of Education (2007B090400076) and Daoqum Chemical Enterprise Ltd.

Received: October 29, 2007

Accepted: January 27, 2008 Published: April 2, 2008

\section{REFERENCES}

1. J.-S. Wang and K. Matyjaszewski, J. Am. Chem. Soc., 117, 5614 (1995).

2. M. Kato, M. Kamigaito, M. Sawamoto, and T. Higashimura, Macromolecules, 28, 1721 (1995).

3. V. Percec and B. Barboiu, Macromolecules, 28, 7970 (1995).

4. K. Matyjaszewski and J.-H. Xia, Chem. Rev., 101, 2921 (2001).

5. M. Kamigaito, T. Ando, and M. Sawamoto, Chem. Rev., 101, 3689 (2001).

6. V. Coessens, T. Pintauer, and K. Matyjaszewski, Prog. Polym. Sci., 26, 337 (2001).

7. M. Lazzari, O. Chiantore, R. Mendichi, and M. A. López-Quintela, Macromol. Chem. Phys., 206, 1382 (2005).

8. a) C. Granel, P. Dubois, R. Jérôme, and P. Teyssié, Macromolecules,
29, 8576 (1996).

b) Y. Kotani, M. Kato, M. Kamigaito, and M. Sawamoto, Macromolecules, 29, 6979 (1996).

9. Y. Liu, L. Wang, and C.-Y. Pan, Macromolecules, 32, 8301 (1999).

10. a) H.-j. Paik, S. G. Gaynor, and K. Matyjaszewski, Macromol. Rapid Commun., 19, 47 (1998).

b) T. Fónagy, B. Ivón, and M. Szesztay, Macromol. Rapid Commun., 19, 479 (1998).

c) K. Matyjaszewski, M. Teodorescu, P. J. Miller, and M. L. Peterson, J. Polym. Sci., Part A: Polym. Chem., 38, 2440 (2000).

11. a) H. G. Börner, K. Beers, K. Matyjaszewski, S. S. Sheiko, and M. Moeller, Macromolecules, 34, 4375 (2001).

b) K. Yamada, M. Miyazaki, K. Ohno, T. Fukuda, and M. Minoda, Macromolecules, 32, 290 (1999).

12. a) K. Matyjaszewski, K. L. Beers, A. Kern, and S. G. Gaynor, J. Polym. Sci., Part A: Polym. Chem., 36, 823 (1998).

b) S. G. Roos, A. H. E. Mueller, and K. Matyjaszewski, Macromolecules, 32, 8331 (1999).

13. L. Jin, P. Liu, J.-H. Hu, and C.-C. Wang, Polym. Int., 53, 142 (2004).

14. a) V. Percec, B. Barboiu, T. K. Bera, M. van der Sluis, R. B. Grubbs, and J. M. J. Frechet, J. Polym. Sci., Part A: Polym. Chem., 38, 4776 (2000).

b) C. L. Fraser and A. P. Smith, J. Polym. Sci., Part A: Polym. Chem., 38, 4704 (2000).

15. a) G.-L. Cheng, P. F. W. Simon, M. Hartenstein, and A. H. E. Müller, Macromol. Rapid Commun., 21, 846 (2000).

b) K. Matyjaszewski, S. G. Gaynor, and A. Kulfan, Macromolecules, 30, 5192 (1997).

c) K. Matyjaszewski, J. Pyun, and S. G. Gaynor, Macromol. Rapid Commun., 19, 665 (1998).

16. a) X.-Y. Chen, D. P. Randall, C. Perruchot, J. F. Watts, T. E. Patten, T. Werne, and S. P. Armes, J. Colloid Interface Sci., 257, 56 (2003). b) J. Pyun and K. Matyjaszewski, Macromolecule, 33, 217 (2000).

17. A. M. Kasko, A. M. Heintz, and C. Pugh, Macromolecules, 31, 256 (1998).

18. B. De Clercq, J. Laperre, and L. Ruys, Prog. Org. Coat., 53, 195 (2005).

19. a) J. K. Oh, D. J. Siegwart, H.-il Lee, G. Sherwood, L. Peteanu, J. O. Hollinger, K. Kataoka, and K. Matyjaszewski, J. Am. Chem. Soc., 129, 5939 (2007).

b) R. E. Richard, M. Schwarz, S. Ranade, A. K. Chan, K. Matyjaszewski, and B. Sumerlin, Biomacromolecules, 6, 3410 (2005).

c) C. Giacomelli, V. Schmidt, and R. Borsali, Macromolecules, 40, 2148 (2007).

20. a) V. Vázquez-Dorbatt and H. D. Maynard, Biomacromolecules, 7, 2297 (2006).

b) F. J. Xu, Y. L. Li, E. T. Kang, and K. G. Neoh, Biomacromolecules, 6, 1759 (2005).

c) M. Licciardi, Y. Tang, N. C. Billingham, S. P. Armes, and A. L. Lewis, Biomacromolecules, 6, 1085 (2005).

21. Ph. Lecomte, I. Drapire, Ph. Dubois, Ph. Teyssié, and R. Jérôme, Macromolecules, 30, 7631 (1997).

22. G. Moineau, C. Granel, Ph. Dubois, R. Jérôme, and Ph. Teyssié, Macromolecules, 31, 542 (1998).

23. Y. Kotani, M. Kamigaito, and M. Sawamoto, Macromolecules, 32, 2420 (1999).

24. a) X.-P. Chen and K.-Y. Qiu, Chem. Commun., 1403 (2000). b) V. C. Gibson, R. K. O'Reilly, D. F. Wass, J. P. White, J. P. Andrew, and D. J. Wlliams, Macromolecules, 36, 2591 (2003).

c) R. K. O'Reilly, V. C. Gibson, J. P. Andrew, J. P. White, and D. J. Wlliams, J. Am. Chem. Soc., 125, 8450 (2003).

25. a) H. Uegaki, Y. Kotani, M. Kamigaito, and M. Sawamoto, Macromolecules, 31, 6756 (1998).

b) R. M. Johnson, P. S. Corbin, C. Ng, and C. L. Fraser, Macromolecules, 33, 7404 (2000).

26. T. Pintauer and K. Matyjaszewski, Coord. Chem. Rev., 249, 1155 
(2005).

27. a) T. E. Patten, J.-H. Xia, T. Abernathy, and K. Matyjaszewski, Science, 272, 866 (1996).

b) K. Matyjaszewski, J.-L. Wang, T. Grimaud, and D. A. Shipp, Macromolecules, 31, 1527 (1998).

28. J.-H. Xia and K. Matyjaszewski, Macromolecules, 30, 7697 (1997).

29. J.-H. Xia, S. G. Gaynor, and K. Matyjaszewski, Macromolecules, 31, 5958 (1998).

30. G. Kickelbick and K. Matyjaszewski, Macromol. Rapid Commun., 20, 341 (1999).

31. J.-H. Xia and K. Matyjaszewski, Macromolecules, 32, 2434 (1999).

32. R. M. Johnson, C. Ng, C. C. M. Samson, and C. L. Fraser, Macromolecules, 33, 8618 (2000).

33. K. Matyjaszewski, B. Gobelt, H.-j. Paik, and C. P. Horwitz, Macromolecules, 34, 430 (2001).

34. J. Qiu, K. Matyjaszewski, L. Thouin, and C. Amatore, Macromol. Chem. Phys., 201, 1625 (2000).

35. W. Tang and K. Matyjaszewski, Macromolecules, 39, 4953 (2006).

36. X.-H. Zhou, H.-B. Zhang, and G.-Y. Zhang, China Patent
CN200610125458.5(06.12).

37. X.-D. Chen and T. C. W. Mak, J. Mol. Struct., 748, 183 (2005).

38. R. N. Keller, H. D. Wycoff, and L. E. Marchi, "Inorganic Syntheses, Vol. 2", W. C. Fernelius, Ed., McGraw-Hill Book Company, Inc. 1946.

39. R. Poli, Angew. Chem. Int. Ed., 45, 5058 (2006).

40. S. Karanam, H. Goossens, B. Klumperman, and P. Lemstra, Macromolecules, 36, 3051 (2003).

41. H.-Q. Zhang, B. Klumperman, W.-H. Ming, H. Fischer, and R. Linde, Macromolecules, 34, 6169 (2001).

42. K. Matyjaszewski, D. A. Shipp, J.-L. Wang, T. Grimaud, and T. E. Patten, Macromolecules, 31, 6836 (1998).

43. R. G. Gilbert, Pure Appl. Chem., 68, 1491 (1996).

44. J.-L. Wang, T. Grimaud, and K. Matyjaszewski, Macromolecules, 30, 6507 (1997).

45. A. Mittal and S. Sivaram, J. Polym. Sci., Part A: Polym. Chem., 43, 4996 (2005).

46. S. Faucher, P. Okrutny, and S. Zhu, Ind. Eng. Chem. Res., 46, 2726 (2007). 